Original Article

\title{
DEVELOPMENT OF QUALITY CONTROL PARAMETERS FOR STANDARDIZATION OF A NOVELMUCILAGE OBTAINED FROM OKRA (ABELMOSCHUS ESCULENTUS (L.) MOENCH) FRUIT
}

\author{
SOMA DAS ${ }^{1}$, ANANYA GHOSH ${ }^{2}$, RUSHAM DAS ${ }^{1}$, GOURANGA NANDI ${ }^{3}{ }^{*}$, LAKSHMI KANTA GHOSH ${ }^{1}$
}

1Department of Pharmaceutical Technology, Jadavpur University, Kolkata 700032, India, ${ }^{2}$ Manipal College of Pharmaceutical Sciences, Manipal, Karnataka, ${ }^{3}$ Department of Pharmaceutical Technology, University of North Bengal, Raja Rammohunpur, Dist Darjeeling, West Bengal, India, 734013

Email: somapharma@gmail.com

Received: 22 Jan 2021, Revised and Accepted: 18 Mar 2021

\begin{abstract}
Objective: The main objective was to focus on qualitative and quantitative analysis of isolated okra mucilage by High-performance Thin Layer Chromatography to set up the quality control parameters for the isolated mucilage.
\end{abstract}

Methods: High-performance thin-layer chromatography (HPTLC) were applied for the identification of components present in methanolic and ethanolic fruit extract of okra at $254 \mathrm{~nm}$ and $356 \mathrm{~nm}$. Quantitative analysis of amino acid ascorbic acid and total polyphenol content was determined.

Results: The results showed that the yield percentage for methanolic and ethanolic fruit extract of the okra fruit mucilage was found to be 13.5 and $12.5 \%$ respectively. HPTLC determination of methanolic and ethanolic okra fruit extract showed the presence of 8 components with Rf values in the range of 0.14 to 0.62 and 0.14 to 0.54 respectively when detected at wavelengths $254 \mathrm{~nm}$ and at $356 \mathrm{~nm}$. The total amino acid in okra fruit methanolic extract was found to be $11.45 \% \mathrm{w} / \mathrm{w}$. The ascorbic acid content in methanolic okra fruit extract and ethanolic okra fruit extract was found to be $0.24 \% \mathrm{w} / \mathrm{w}$ and $0.18 \% \mathrm{w} / \mathrm{w}$ respectively. The total phenolic contents (tannic acid equivalents, $\mathrm{mg} / \mathrm{g}$ ) in the methanolic and ethanolic okra fruit extracts were calculated to be $4.6 \% \mathrm{w} /$ wand $5.3 \% \mathrm{w} / \mathrm{w}$ respectively.

Conclusion: The data revealed dual benefits like it can act as a potential novel functional ingredient with health-promoting application due to the presence of ascorbic acid and total phenolics contents and at the same time the data provided guidelines for quality control parameters for the isolated okra fruit

Keywords: Mucilage, Okra. HPTLC, Quality control parameters

(c) 2021 The Authors. Published by Innovare Academic Sciences Pvt Ltd. This is an open access article under the CC BY license (https://creativecommons.org/licenses/by/4.0/) DOI: https://dx.doi.org/10.22159/ijcpr.2021v13i3.42091 Journal homepage: https://innovareacademics.in/journals/index.php/ijcpr

\section{INTRODUCTION}

Nature has blessed us with a very rich and plethora of botanical wealth and a huge number of valuable medicinal plants which play a pivotal role in modern medicine as well as in traditional medicine for centuries to treat various diseases worldwide since time immemorial [1]. Green pharmaceuticals are demanding popularity and importance and acceptance is increasing progressively because immense opportunities for new drug discoveries are provided by keen interest in plant-derived drugs due to the fact that "green medicines" have a valuable approach for benefits of humankind moreover in order to search for economical ingredients and enabling companies to enhance their existing product the cost of drug development plays pivotal role in order to cope with worldwide challenges and competition. For the pharmaceutical companies to flourish new drug delivery systems and to upgrade the products with a view to improve efficiency, enhance functionality and reduce the cost of drugs, pharma world orients towards designing novel excipients from natural sources Novel and upgraded excipients are being evolved to meet the specific needs of advanced drug delivery systems [2] The natural excipients are environmentally friendly economical and easily acquirable [3]. Herbal excipients are being explored and employed in dosage formulations and drug delivery research [4].

Mucilages can be classified as herbal excipients which are safe and eco-friendly, find applications in pharmaceutical dosage formulations. Mucilages find wide range of applications in biphasic liquid dosage forms, such as thickeners in oral liquids binding, disintegrating agent, suspending and emulsifying agent, stabilizing and gelling agents, film-forming agents in transdermal and periodontal films and as gel base for tropical application [5].

In recent years it has been observed that dietary fibres obtained from plant i. e mucilage from fruits are getting tested for their use in various fields like nutraceuticals pharmaceutical and other nonmedical like beautifying industries because for various health benefits and they appear as a suitable source of soluble dietary fiber. Several phytocompounds are being incorporated in the mucilage that functions as antioxidant, antidiabetic, anti cancer-immune stimulating, anti-inflammatory and other alternative medicines and therapeutics [6] The mucilage is soluble in cold water, can dissolve, disperse and swell in water to form gelatinous colloids [7].

Fruits are the best source of soluble dietary fiber mucilage. Presence of mucilage is a characteristic feature of the family Malvaceae One such interesting plant belonging to Malvaceae is Okra (Abelmoschus esculentus) or bhendi also known as ladies finger, a vegetable crop of significance and is in demand throughout the world.

Okra is harvested at least every other day and it is largely harvested so toxicological studies are not required and it is also considered as economical [8]. Moreover, Okra mucilage has viscous propertiesfor which sticky mass is produced that helps to release the drug in a slow manner from solid dosage form to provide better tensile strength [9].

From the review of documentation, it has been observed that inadequate physicochemical and phytochemical properties of okra mucilage being studied [10]. Comprehensive analysis to set up quality control standards and identification profiling of the okra mucilage is not being reported.

Therefore, the main objective of this study was to isolate and analysis of the mucilage in order to exhibit the fundamental characteristics and quality control parameters of okra mucilage, determination of some bioactive compounds through the application of high-performance liquid chromatography to furnish insight to its potential use in the World of Pharma and World of Nutrition. 
Thus the present investigation was undertaken to focus of isolation of mucilage from okra fruit followed by phytochemical and physicochemical evaluation and development of chromatographic profile of the methanolic and ethanolic extracts. Toestablish the authenticity of okra mucilage the different parameters are subjected for qualitative and quantitative analysis. HPTLC profiling of the two different extracts of the okra mucilage confirm about the presence of various phytochemicals that gives an indication of potential medicinal and nutritive value for human welfare.

Also the investigation of amino acid, ascorbic acid and polyphenols in okra mucilage was done to indicate the presence of bioactive compounds.

Thus the present investigation involved isolation of mucilage from okra fruit followed by phytochemical and physicochemical evaluation and development of chromatographic profile of the methanolic and ethanolic extracts. The authenticity of okra mucilage may be established by the parameters studied through various analysis HPTLC profiling of the two different extracts of the okra mucilage confirm about the presence of various phytochemicals that gives an indication of potential medicinal and nutritive value for human welfare.

Bioactive compounds derived from plant products are alluring candidates for drug development [11].

Identification of the components present in the okra mucilage were performed at two different wavelengths 254 and $356 \mathrm{~nm}$ by highperformance thin-layer chromatography

The investigation of amino acid, ascorbic acid and polyphenols in okra mucilage were performed to indicate the presence of bioactive compounds by the modern high-performance thin-layer chromatography (HPTLC). ThusGreen analytical technique was developed to modify the existing methods in order to reduce the use of hazardous chemicals.

\section{MATERIALS AND METHODS}

All chemicals and solvents used were of analytical grade and procured from laboratory and throughout the whole experiment distilled water was used.

Various pharmacognostic methods such as preliminary phytochemical/physicochemical studies were performed including analysis ofash values, moisture content, viscosity, swelling index (SI), pH value,etc. The parameters like bulk density, tapped density, Hausner's ratio and angle of repose, was determined for the study of powder characterization. Qualitative tests for organic constituents, and test for mucilage were also carried out. Analytical study was performed with high-performance thin-layer chromatography (HPTLC) for setting appropriate standards.

\section{Collection and authentication of plant material}

Okra (Abelmoschus esculentus) belonging to family Malvacea was selected on the basis of traditional applications and pharmacological reports. The plant sample (1) has been collected from Raj Kharswan P. S. Rajkharswan Dt. Seraikella-Kharswan, Jharkhand, India on 25.04.2018 and sample no(2) has been collected from Prasadpur, P. O. Kustia P. S. Sonarpur, Dt. South 24 Parganas, West Bengal, India on 03.07.2018. The plants were identified and authenticated by by Dr. Rajiv Gogai-ScientistE of Central National Herbarium-BSI-Howrah. Fresh plant material was washed properly under running tap water, and air dried.

\section{Sample isolation}

The method used for the extraction of Okra gum was based on the procedure by Tavakoli et al. [12]

About $5 \mathrm{~kg}$ fresh okra fruits were collected After proper washing fresh fruits were sliced, The seeds are devoid of any mucilage and the removal of seeds done prior to extraction. The sliced fruits were allowed to soak in distilled water for overnight and extracted with warm water water. $1 \% \mathrm{w} / \mathrm{v}$ of sodium meta bisulphite was added to the slurry. The crude mucilage being filtered. Heated with stirred continuous at $60{ }^{\circ} \mathrm{C}$ for approximately $4 \mathrm{~h}$. Then the concentrated solution was filtered and cool at $4^{\circ}-6^{\circ} \mathrm{C}$ Extracted gum was isolated in acetone. The mucilage was washed with acetone and the mucilage was filtrated. The mucilage was allowed to air dry and pressed and was further dried to constant weight at $35-45{ }^{\circ} \mathrm{C}$ in hot air oven. Grinding of solidified mucilage was done and sieved using sieve no \#100 and then stored in dessicator for further us [13].

\section{Percentage yield of isolated mucilage}

Determination of the percentage yield was done for extracted mucilage based on the amount of fresh okra and the amount of dry mucilage obtained depending upon solvents and expressed as mucilage percentage (\%). For calculation of the percentage yield ratio between weight of dried mucilage obtained and weight of fresh material. By applying the formula the yield of mucilage was calculated by weighing the dried isolated mucilage and weight of fresh material [14].

$$
\text { Percentage yield }=\text { Weight of dried mucilage obtained } / \text { weight of }
$$
drug used $\times 100$.

\section{Physicochemical analysis of the okra mucilage}

The isolated mucilage was subjected to Preliminary identification tests,viz. ruthenium red and Molisch's test, organoleptic evaluation and other preliminary phytochemical tests which were carried out by standard procedures were performed for the isolated mucilage

The observations of the entire test were made in triplicate and represented as an average of successive measurements. Other tests applied in the study were as follows:

\section{Solubility}

Solubility of the mucilage powder was determined in different solvents such as water, chloroform ethanol, acetone, petroleum ether and benzene [14].

\section{Determination of the $\mathrm{pH}$ of mucilage}

Dispersion of $1 \%$ mucilage in $25 \mathrm{ml}$ of distilled water by shaking for $5 \mathrm{~min}$ and determined the $\mathrm{pH}$ of mucilage solution using a digital $\mathrm{pH}$ meter (Merck, Mumba) [15]

\section{Organoleptic evaluation}

Organoleptic evaluation is the simplest means of evaluation for the determination of the identity and purity to ensure the quality of a particular drug characters such as shape, size, colour, odour, taste and texture. The preliminary identification test using ruthenium red test, were conducted to confirm the nature of mucilage and to determine purity; Different phytoconstituent Test for alkaloid, carbohydrates, flavonoids, steroids, amino acids, saponins, tannins and phenols was carried out by standard test procedures [16]

\section{Fluorescence analysis}

Fluorescence analysis is one of the pharmacognostic procedures useful in the identification of authentic samples and recognizing adulterants [17]

Fluorescence analysis was determined on the powdered drug that was treated with various solvents. The study was conducted under daylight, UV light of short and long wavelengths. Visible and ultra violet light, was used for study of the behaviour of okra mucilage after treatment with various reagents like Dilute ammonia, Sulphuric Acid, Nitric Acid, Acetic acid, Picric Acid, Acetonitrile and water. The mucilage showed typical coloration upon treatment with multifarious chemical reagents

Several physicochemical analysis such as the percentage of ash values, total ash and Insoluble ash values were carried out on the methanolic and Ethanolic Extracts of Okra Mucilages as per prescribed in Indian Pharmacopoeia and Ayurvedic Pharmacopoeia of India, and WHO guidelines on quality control methods for medicinal plant materials. Several physicochemical analysis such as the percentage of ash values, Total ash and Insoluble ash values were carried out on the methanolic and Ethanolic Extracts of Okra Mucilage.

\section{Ash values}

Ash values such as total ash, acid insoluble ash and water-soluble ash was determined according to Indian Pharmacopoeia 1996 


\section{Loss on drying}

To a pre-weighed crucible. about $1 \mathrm{~g}$ of the mucilage was placed. The sample for analysis was oven-dried at $105{ }^{\circ} \mathrm{C}$ for $2 \mathrm{~h}$. Then transferred into a desiccator oven-dried sample and allowed to cool for $30 \mathrm{~min}$. The oven-drying was repeated until a constant weight was obtained. Calculation of Loss on Drying was done by using the formula: [18]

Loss on Drying (LOD):

$$
\%=100(\mathrm{X} 1-\mathrm{X} 2) / \mathrm{X} 1
$$

Where: $\mathrm{X} 1=$ initial weight of mucilage $\mathrm{X} 2=$ final weight of the mucilage after drying

\section{Swelling index of isolated mucilage}

One gram of okra mucilage powder was accurately weighed and transferred to a $100 \mathrm{ml}$ stoppered measuring cylinder. The initial volume of the powder occupied by the measuring cylinder was noted. Then distil water was added to make up the volume to 100 $\mathrm{ml}$. The stoppered cylinder was shaken gently and set aside for 24 hour. The volume occupied by the mucilage was recorded after $24 \mathrm{~h}$ [18].

Swelling index (SI) is expressed as a percentage and calculated as

$$
\text { Swelling Index }=\frac{\text { Initial weight of the mucilage }- \text { Final weight of the mucilage }}{\text { Initial weight } \times 100}
$$

\section{Phytochemical analysis of the isolated mucilage}

The presence of phytoconstituents were determined as per standard protocol. The preliminary phytochemical screening of the powder extracts were dissolved in their respective solvents and were subjected to qualitative tests for the detection of various primary and secondary plant metabolites such as alkaloids, tannins, flavonoids, phenol, carbohydrates, amino acids, steroids, terpenoids, using standard procedure.

\section{Qualitative method of analysis of phytoconstituent}

Phytoconstituents present in the finely powdered samples of the methanolic and ethanolic extract were subjected to different qualitative chemical analysis. The okra extracts of methanolic and ethanolic aqueous solutions were assessed for the existence of the phytochemical analysis by using the following standard methods [20]

\section{Test for mucilage ((Ruthenium red test)}

To a small quantity of the methanolic and ethanolic extract a drop of ruthenium red solution was added placed on a glass slide and observed under microscope.

\section{Test for alkaloids}

$0.2 \mathrm{~g}$ of each of the methanolic andethanolic crude extracts (separately), $2 \mathrm{ml}$ of $1 \% \mathrm{HCl}$ was mixed, warmed and filtered. To the $2 \mathrm{ml}$ of the filtrate both reagents Maeyer's and Dragendorff's were added and then kept for observation for the present or absent of alkaloids

\section{Test for tannin}

$5 \mathrm{~g}$ of each methanolic and ethanolic extract was mixed with $10 \mathrm{ml}$ distilled water, then filtered, and ferric chloride reagent added to the filtrate. Deep blue color if observed i. e tannins were present in the sample.

\section{Test for flavonoids}

A small quantity of methanolic band ethanolic extract was dissolved in few ml of ethanol $(95 \% \mathrm{v} / \mathrm{v})$ and added few drops of concentrated hydrochloric acid with small amount of addition of magnesium metal. Presence of flavonoids are detected by the development of colour within a minute like pink, crimson or magenta color

\section{Test for anthraquinone}

$5 \mathrm{ml}$ of each of the methanolic and ethanolic crude extracts (separately) was boiled with $10 \mathrm{ml}$ of sulfuric acid (H2SO4) and filtered. To the filtrate few $\mathrm{ml}$ of chloroform. is added The chloroform layer was pipetted into another test tube and added $1 \mathrm{ml}$ of dilute ammonia was added. Observation for any change of colour was noticed

\section{Test for sugar}

The methanolic and ethanolic extracts were treated with the minimum quantity of anthrone and added few drops of concentrated sulphuric acid and then heated. Observation for any change of color from green to purple showed the presence of sugar.

\section{Test for phenols}

To $2 \mathrm{ml}$ of extracts of methanolic and ethanolic extract added $4 \mathrm{ml}$ of distilled water, and few drops of $10 \%$ aqueous ferric chloride solution. The presence of phenol was determined by the development of blue or green colour.

\section{Micromeritic analysis}

\section{Bulk density}

Determination of the bulk density of mucilage was performed by putting the accurately weighed $(10 \mathrm{~g})$ of methanolic and ethanolic extract into a $100 \mathrm{ml}$ graduated cylinder, and without disturbing the cylinder the volume of powdered samples was observed, to give the bulk volume and was calculated using the following formula [21] as below:

Bulk density $=$ Weight of powder/Volume occupied by powder $\times 100$

\section{Tapped density}

For the determination of the tapped density weighed quantity $(10 \mathrm{~g})$ of powder mucilage of both methanolic and ethanolic extract was poured into a $100 \mathrm{ml}$ graduated cylinder and dropped on hardwood surface on tiles for3 times from a height of $2.5 \mathrm{~cm}$. It was calculated as per the formula (Aulton ME,-2002) as below:

Tapped density $=$ Weight of powder $/$ Final volume after tapping $\times 100$

\section{Carr's index determination}

Calculation of Carr's Index was found out from the value of bulk density and tapped density. Carr's index determination were performed as below equation:

$$
\text { Carr's Index }=\frac{\text { Tapped density ---Bulk density }}{\text { Tapped Density }} \times 100
$$

\section{Hausner's ratio determination}

Measure of flowability of the mucilage powder of both methanolic and ethanolic extract was calculated by the following equation. The low value of Hausner' sratio indicates that the mucilage powder has high flow ability. The value above 1.25 Hausner'sratioindicate poor flow. ((Aulton ME,-2002)

$$
\text { Hausner's ratio }=\text { Tapped density } / \text { Bulk density }
$$

\section{Angle of repose}

Angle of repose by fixed funnel method was used for flow characteristics of isolated mucilage powder Angle of repose was calculatedby using formula [22]

$$
\operatorname{Tan} \emptyset=2 \mathrm{~h} / \mathrm{D}
$$

$\mathrm{h}=$ Height of powder (from graph paper to tip of funnel),

$\mathrm{D}=$ Mean diameter of the powder

High performance thin layer chromatography (HPTLC) analysis

A CAMAG HPTLC system (Switzerland) comprising of CAMAG Linomat 5 applicator and CAMAG TLC Scanner 3 operated by win CATS software [ver. 1.3.3]. The CAMAG twin trough glass tank $(10$ $\mathrm{cm} \times 10 \mathrm{~cm}$ ) used for development and CAMAG UV cabinet light used for manual view of TLC spots.

Procedure for the identification of components in Okra methanolic and ethanolic extract

$100 \mathrm{mg}$ each of the methanolic extract and ethanolic extract of Okra powder was dissolved in $10 \mathrm{ml}$ of the suitable solvent and centrifuged at 
$6500 \mathrm{rpm}$ for $5 \mathrm{~min}$. These supernatant was used as test solution for HPTLC analysis to identify the components in Okra mucilage.

The analysis was carried out by application of the $5 \mathrm{mg} / \mathrm{ml}$ methanolic extract of Okra mucilage and $10 \mathrm{mg} / \mathrm{ml}$ ethanolic extract of Okra mucilageon HPTLC Precoated silica gel $60(10 \mathrm{~cm} \times 10 \mathrm{~cm})$ F254 plate [Merck, Darmstadt, Germany, 1.05554.0007] at different volumes 5,10,20 and $40 \mu \mathrm{l}$. were applied with proper supply of nitrogen gas to provide an inert environment to the sampling process. The plate was developed using the mobile phase Ethyl acetate: Acetic acid: formic acid: water: :100:11:11:25in CAMAG twin trough glass Chamber $(20 \times 10 \mathrm{~cm})$ up to the distance of $85.8 \mathrm{~mm}$ at room temperature. The plates were air-dried and viewed using CAMAGTLC Scanner at wavelength $254 \mathrm{~nm}$ and $356 \mathrm{~nm}$. 8 numbers of tracks were studied and the distance between the tracks maintained as $11.4 \mathrm{~mm}$ with band length of $6.0 \mathrm{~mm}$.

Procedure to estimate amino acid in okra methanolic and ethanolic extract

Methionine (100 ppm) and Arginine (100 ppm) standards and extracts of Okra mucilage were spotted on a HPTLC Precoated silica gel $60(10 \mathrm{~cm} \times 10 \mathrm{~cm})$ F254 plate [Merck, Darmstadt, Germany, 1.05554.0007] at different volumes of 10 and $30 \mu \mathrm{l}$. Ascending development of the plate was carried out to a distance of $84.2 \mathrm{~mm}$ at room temperature with a mobile phase of n-butanol: Acetone: Acetic Acid: Water $(7: 7: 2: 4 \mathrm{v} / \mathrm{v} / \mathrm{v} / \mathrm{v})$. After development, the plates were air-dried and dipped in $0.3 \%$ ninhydrin in n-butanol solution and the plates were dried in hot air oven maintained at temperature $120^{\circ} \mathrm{C}$ for $20 \mathrm{~min}$. The quantitative analyses of the compounds were done by scanning the plates at $610 \mathrm{~nm}$ with a CAMAG TLC scanner 3 operated by win CAT software at $20 \mathrm{~nm} / \mathrm{s}$. The total 20 numbers of tracks with a distance of $11.0 \mathrm{~mm}$ were scanned and the detection of spots with matching Rf values of the amino acids were calculated.

Formula:

$$
\begin{aligned}
& \text { Percentage of all amino acids with respect to methionine: } \\
& =\frac{\text { Sample area X Standard dilution X purity }}{\text { Standard area X sample Dilution X } 10} \times 100
\end{aligned}
$$

Procedure to estimate ascorbic acid in okramethanolic and ethanolic extract

The test solutions of Okra ethanolic extract $10 \mathrm{mg} / \mathrm{ml}$ and Okra methanolic extract $10 \mathrm{mg} / \mathrm{ml}(5,10,20$ and $40 \mu \mathrm{l}$ of each) and the standard Ascorbic Acid were coated on a pre-coated TLC aluminum silica gel-60F 254 (Merck, Germany) $(20 \mathrm{~cm} \times 10 \mathrm{~cm})$. After the application of sample, the chromatogram was developed in Twin trough glass chamber $20 \times 10 \mathrm{~cm}$ saturated with the mobile phase ethanol: Acetic Acid (9.5:0.5) for $5 \mathrm{~min}$. The Rf values were recorded by win cats software

\section{Spectrophotometric analysis of total polyphenol content present in methanolic and ethanolic extract}

Stock solutions were prepared at a concentration of $1 \mathrm{gm} / 100 \mathrm{ml}$ of methanolic and ethanolic extract of okra mucilage and subjected to spectrophotometric measurements to determine the total phenolic content.

\section{Determination of total polyphenol content}

Folin Denim's method reagent was employed for the determination of the total phenolics of the extracts explained by Singleton and Rossi with slight modifications. Sample and standard readings were made using a spectrophotometer (UV Analyst-CT 8200.) at $765 \mathrm{~nm}$ against the reagent blank.

Tannic acid (TA) was used as a reference standard and calculated using the following linear equation based on the calibration curve of tannic acid;

The extract (1 mg. ml-1) was mixed with $7.5 \mathrm{ml}$ of distilled water, $1 \mathrm{ml}$ of $20 \%$ sodium carbonate and Folin; sDenim; s Reagent. (0.5 ml)In a water bath for $60 \mathrm{~min}$ at $40^{\circ} \mathrm{C}$ the mixture was allowed to stand All the experiments were made to run in duplicate. The total phenolic contents were determined from the linear equation of a standard curve prepared with tannic acid. The content of total phenolic compounds expressed as $\mathrm{mg} / \mathrm{g}$ tannic acid equivalent (TA) of dry extract. The total polyphenol content in Okra Mucilage was calculated using UV-Vis Spectrophotometer was found from the fig. 15

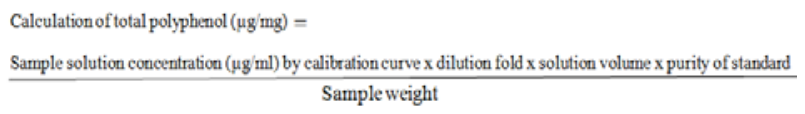

\section{RESULTS AND DISCUSSION}

\section{Percentage yield of okra mucilage}

In the present research analysis, after isolation of the mucilage from the fresh fruit of okra by means of methanol and ethanol,. the percentage yield of purified extracts was found to be 13.5 and 12.5 $\% \mathrm{w} / \mathrm{w}$ respectively and was mentioned in table 1 .

Table 1: Percentage yield of okra mucilage

\begin{tabular}{lll}
\hline Plant's name & Percentage yield (\%) & \\
\hline Abelmoschus esculentus fruits & Methanolic & Ethanolic \\
& 13.5 & 12.5 \\
\hline
\end{tabular}

Table 2: Organoleptic characteristic of okra mucilage

\begin{tabular}{lll}
\hline S. No. & Parameters & Observation \\
\hline 1 & Description & Brownish \\
2 & Odour & Characteristic \\
3 & Shape & Irregular \\
4 & Taste & Mucilaginous \\
\hline
\end{tabular}

Table 3: Solubility profile of okra mucilage

\begin{tabular}{llll}
\hline S. No. & Name of solvent & Extract & Solubility parameter \\
\hline 1 & Warm water & a)Methanol & Solubility \\
& b)Ethanol & Swell to form a gel \\
2 & Cold water & $\begin{array}{l}\text { a)Methanol } \\
\text { b)Ethanol } \\
\text { a)Methanol } \\
\text { b)Ethanol }\end{array}$ & Insoluble \\
3 & Ethanol & $\begin{array}{l}\text { a)Methanol } \\
\text { b)Ethanol }\end{array}$ & Insoluble \\
4 & Acetone & $\begin{array}{l}\text { a)Methanol } \\
\text { b)Ethanol } \\
5\end{array}$ & a)Methanol \\
b)Ethanol & Insoluble \\
6 & Menzene & Insoluble \\
\hline
\end{tabular}




\section{Organoleptic characteristic of okra mucilage}

Evaluation for the isolated mucilage was performed for their organoleptic properties such as colour, odour shape and taste. The results are summarized in table 2. Result observed was brownish, odourless, tasteless, rough and irregular in shape.

\section{Solubility profile of okra mucilage}

The solubility profile of okra mucilage methanolic and ethanolic extract in different solvents are summarized in table 3. From the resultsit was evident that okra mucilage is soluble in warm water, slightly soluble in cold water to form gel and insoluble in ethanol, benzene, methanol, acetone.

\section{Physicochemical analysis of the okra mucilage}

The physicochemical analysis of Okra Mucilage are summarized in table 6. The $\mathrm{p}_{\mathrm{p}}$ of $1 \% \mathrm{w} / \mathrm{v}$ solution of methanolic and ethanolic Okra extract in distilled water at $25{ }^{\circ} \mathrm{C}$ was found to be 6.60 and 6.80 respectively. Thus the obtained $\mathrm{pH}$ of extracts of okra mucilage indicates that this mucilage will be less irritating to GIT and suitable for various type of formulation including suspending agent in suspension. The loss on drying of the Okra methanolic and ethanolic extract was found to be 7.86 and $8.10 \%$ respectively. The results indicates that mucilage need to be stored in air-tight containers as it is hygroscopic Ash values were calculated for both methanolic and ethanolic extract to characterize mucilage; for methanolic extract total ash, acid insoluble ash and water-soluble ash were found 9.69\% 1.21\% and $4.38 \%$ respectively. For ethanolic extract total ash, acid insoluble ash and water-soluble ash were found to be $10.0 \%, 1.0 \%$ and $4.60 \%$ respectively. The isolated mucilage was also studied for swelling index. The swelling index was found to be $78.62 \%$ in water, $66.45 \%$ in $0.1 \mathrm{~N}$ HCL and 48.65\%in Phosphate buffer for methanolic extract. For ethanolic extract the swelling index was found to be $77.85 \%$ in water, 65.42 \%in 0.1N HCL and 47.56 \%in Phosphate buffer.

Table 4: Physicochemical analysis of okra mucilage

\begin{tabular}{|c|c|c|c|}
\hline S. No. & Experimental studies & Extracts & Observations in \% \\
\hline \multirow[t]{2}{*}{1} & Total Ash Value & a) Methanolic & a) 9.69 \\
\hline & & b) Ethanolic & b) 10 \\
\hline \multirow[t]{2}{*}{2} & Acid Insoluble Ash Value & a) Methanolic & a) 1.21 \\
\hline & & b) Ethanolic & b) 1.0 \\
\hline \multirow[t]{2}{*}{3} & Water soluble ash value & a) Methanolic & a) 4.38 \\
\hline & & b) Ethanolic & b) 4.60 \\
\hline \multirow[t]{6}{*}{4} & Swelling Index- & a) Methanolic & i) $78.62 \%$ in water \\
\hline & & b)Ethanolic & ii) $66.45 \%$ in HCL \\
\hline & & & iii) $48.65 \%$ inphosphate buffer \\
\hline & & & i) $77.85 \%$ in water \\
\hline & & & ii) $65.42 \%$ in HCL \\
\hline & & & iii) $47.56 \%$ inPhosphate Buffer \\
\hline \multirow[t]{2}{*}{5} & $\mathrm{pH}$ of $1 \% \mathrm{w} / \mathrm{v}$ Solution & a) Methanolic & i) 6.60 \\
\hline & & b) Ethanolic & ii) 6.80 \\
\hline \multirow[t]{2}{*}{6} & Loss on Drying & a) Methanolic & i) $7.86 \%$ \\
\hline & & b) Ethanolic & II) $8.10 \%$ \\
\hline
\end{tabular}

\section{Fluorescence analysis}

The fluorescence Analysis exhibited by Okra Mucilage are summarized in table 5 which showed that the isolated mucilage which was put under long ultra violet light after treatment with various chemical reagents produces range of brownish colour. The characteristic fluorescent properties obtained from the table 4 could be set up as a quality control standard for the identification and authentication of okra mucilage its crude form. Also the contents of this table could act as a specification to check if any adulteration present.

Table 5: Fluorescence analysis exhibited by okra mucilage

\begin{tabular}{llll}
\hline Powdered drug & Visible/day light & UV 254 nm (short) & UV365 nm (long) \\
\hline Powdered drug as such & Light brown & brown & Yellowish brown \\
Powder+dil NH3 & Yellowish brown & Light brown & brown \\
Powder+conc HNO3 & Brown & Blackish Brown & Dark brown \\
Powder+10\% NaOH & Yellowish brown & Dark Yellowish brown & Bluish brown \\
Powder+1M H2SO4 & Brown & Dark brown & Blackish brown \\
Powder+10\% FeCl3 & Brown & Dark brown & Blackish brown \\
Powder+10\% Iodine & Yellowish brown & Dark brown & Blackish brown \\
Powder+Methanol & Light brown & Yellowish brown & Brownish black \\
\hline
\end{tabular}

Powder characterization (Micromeriticproperties) of isolated mucilage

In table 6 micromeriticanalysis of extracted Okra Mucilage were summarised for the powder mucilage such as bulk density, tapped density, Carr's index, angle of repose, for calculating the flow behavior of the mucilage, and all the values were found within the range

The good flow property was determined from the angle of repose of the isolated mucilage and was found to be 31.40 and 31.50 $( \pm 0.30)$. The Bulk density for methanolic and ethanolic was found to be 0.605 and 0.620 respectively. Tapped density were found to be $0.715 \pm 0.02$ and $0.0725 \pm 0.02 \mathrm{~g} / \mathrm{ml}$, respectively. Hausner's
Ratio for methanolic and ethanolic extract was found to be 1.18 and 1.16 respectively.

\section{Phytochemical screening}

The isolated sample was subjected to qualitative identification; and qualitative analysis studies confirmed the presence of carbohydrate, mucilage, phenols, tannins and flavonoids in the okra mucilage extract Confirmation for the identification of isolated mucilage was performed by color reaction with ruthenium red and molisch's reagent both for methanolic and ethanolic extract This can be considered as evidence for purity of the isolated mucilage as mentioned in table 7. Other phytoconstituents were summarised in table 7 
Table 6: Micrometric analysis of extracted okra mucilage

\begin{tabular}{lll}
\hline Parameters & Extracts & Observation \\
\hline Bulk density $(\mathrm{gm} / \mathrm{ml})$ & Methanolic & $0.605 \pm 0.02$ \\
& Ethanolic & $0.620 \pm 0.02$ \\
Tapped density $(\mathrm{gm} / \mathrm{ml})$ & Methanolic & $0.715 \pm 0.02$ \\
& Ethanolic & $0.725 \pm 0.02$ \\
Carr's index & Methanolic & $15.38 \pm 0.01$ \\
& Ethanolic & $14.48 \pm 0.01$ \\
Hausner's ratio & Methanolic & $1.18 \pm 0.02$ \\
& Ethanolic & $1.16 \pm 0.02$ \\
Angle of ratio & Methanolic & $31.40 \pm 0.30$ \\
& Ethanolic & $31.50 \pm 0.30$ \\
\hline
\end{tabular}

Table 7: Phytochemical investigation of Okra methanolic and ethanolic fruit extract

\begin{tabular}{|c|c|c|c|}
\hline Chemical properties & Test & Observations & Observations \\
\hline & & Methanolic & Ethanolic \\
\hline Mucilage & Ruthenium Red & +++ & +++ \\
\hline Alkaloids & Dragendroff; s Test & - & - \\
\hline Carbohydrates & Molisch's Test & +++ & +++ \\
\hline Glycosides & Brontrager's Test & - & - \\
\hline Phenols & Ferric Chloride Test & +++ & ++ \\
\hline Flavanoids & Ammonia Test & +++ & +++ \\
\hline Tannins & Ferric Chloride Test & +++ & ++ \\
\hline Saponins & Froth Test & - & - \\
\hline Proteins and Amino acids & Ninhydrin Test & +++ & ++ \\
\hline Fixed oil & Spot test & - & - \\
\hline Sugar & Benedicts Test & ++ & ++ \\
\hline Uronic Acid & $\begin{array}{l}\text { Boiled in } \mathrm{HCl} \text { in the presence of } \\
\text { naphthoresorcinol }\end{array}$ & +++ & ++ \\
\hline
\end{tabular}

Sign: ---indicates absent: +indicates minimum:++indicates Moderate:+++indicates Maximum.

\section{High-performance thin-layer chromatography}

\section{For the identification of components in okra mucilage}

HPTLC chromatogram fingerprinting was performed for bothmethanolic and ethanolic extract at $254 \mathrm{~nm}$ and $356 \mathrm{~nm}$ with 8 numbers of tracks.

HPTLC determination of mucilage methanolic and ethanolic extract showed the presence of 8 components with Rf values in the range of
0.14 to 0.62 and 0.14 to 0.54 respectively when detected at wavelengths $254 \mathrm{~nm}$ and at356 $\mathrm{nm}$. The densitogramfor both methanolic and ethanolic extract of okra mucilage being displayed in fig. 1. The peaks of okra ethanolic extract being displayed at fig. 2 and fig. 3. Table 9 depicts the high-performance thin-layer chromatography densitogram and peaks of methanolic extract of okra mucilage at $254 \mathrm{~nm}$ and $356 \mathrm{~nm}$. The peaks being displayed at fig. 4 and fig. 5 . The $\mathrm{Rf}$ value in the range 0.10 to 0.88 was same for both Methanolic and Ethanolic extract.

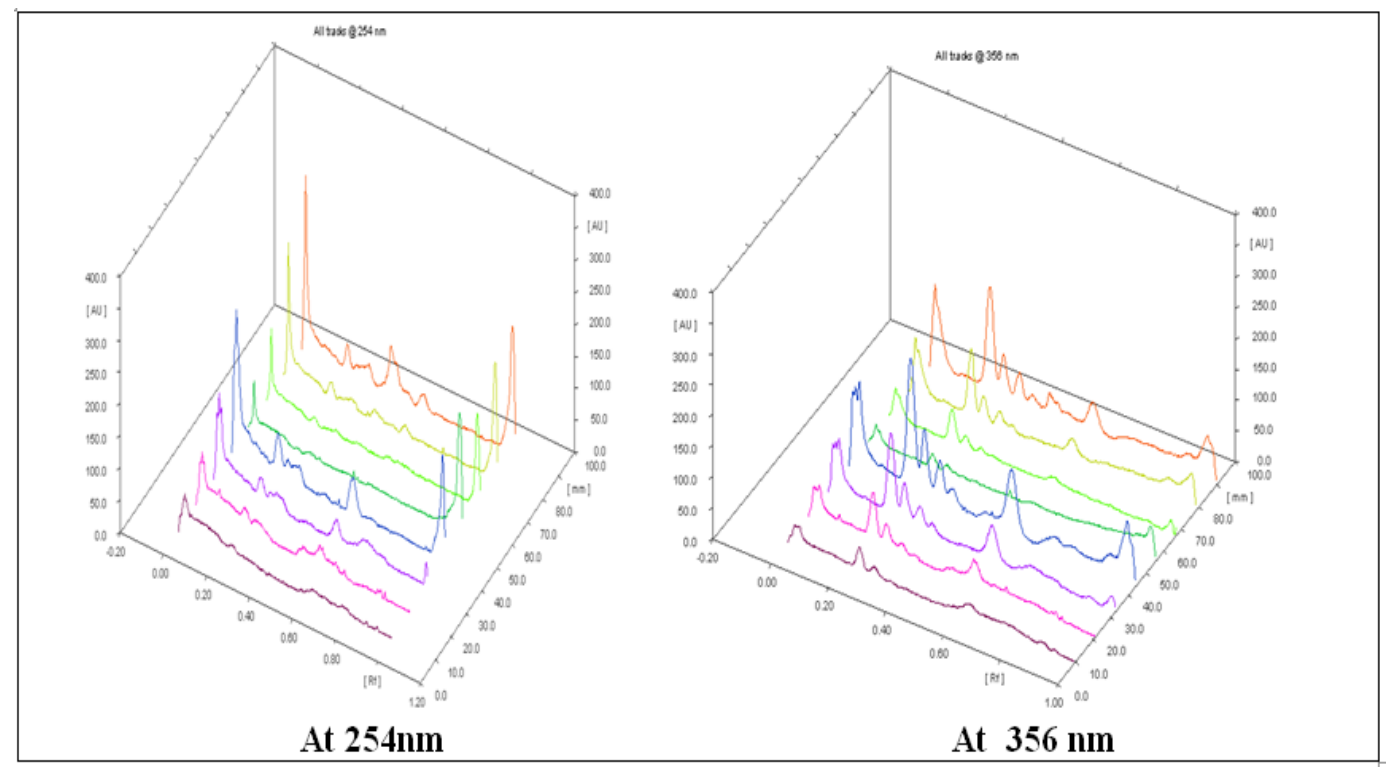

Fig. 1: High-performance thin-layer chromatography fingerprinting overlay of ethanolic and methanolic extract of okra mucilage at 254 $\mathrm{nm}$ and $356 \mathrm{~nm}$. respectively: no of tracks: 8 


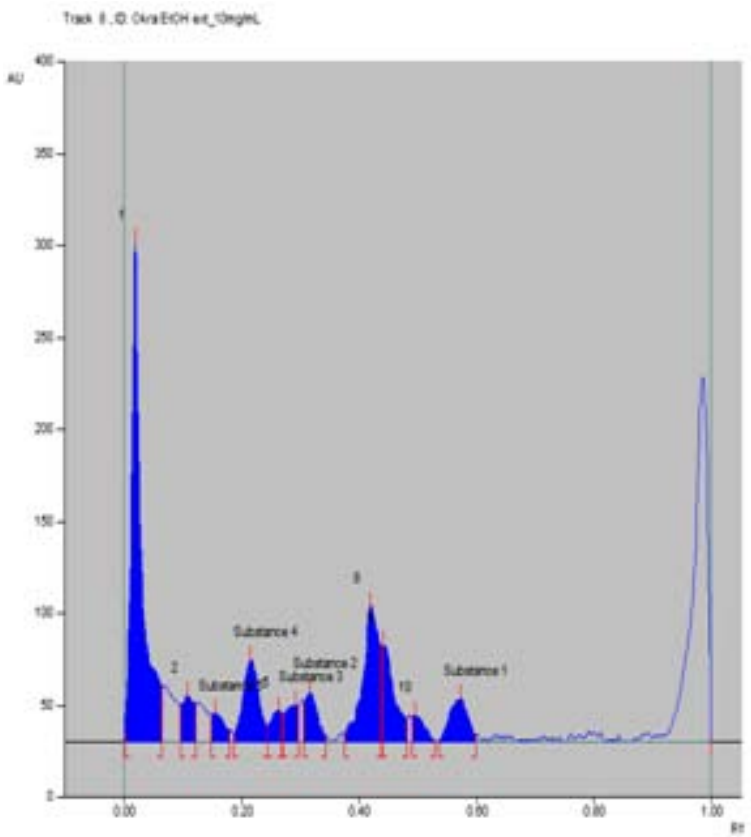

Fig. 2: Peak display of okra EtOH at $254 \mathrm{~nm}$

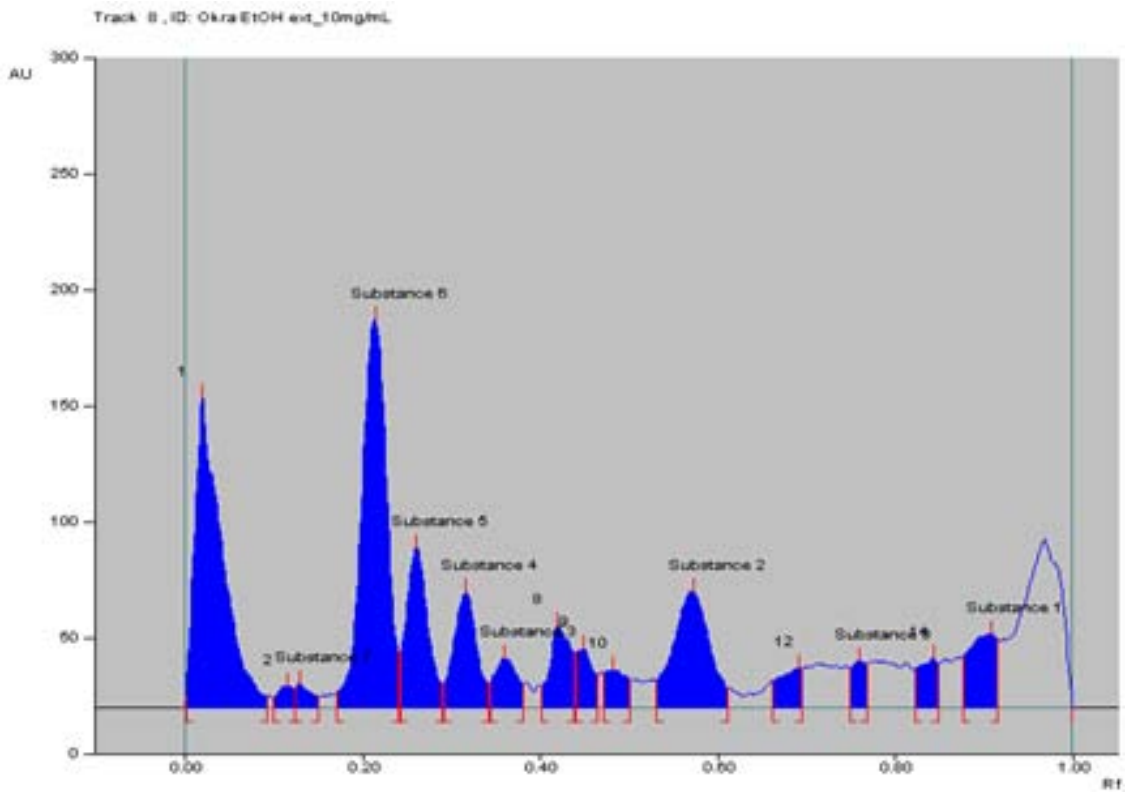

Fig. 3: Peak display of okra EtOH at $356 \mathrm{~nm}$

Table 8: High-performance thin-layer chromatography densitogram and peaks of ethanolic extract of okra mucilage at 254 nm and 356 nm, 8A Track 8: ID of Ethanolic Ext at $10 \mathrm{mg} / \mathrm{ml}$ at $254 \mathrm{~nm}$, Peak table with retention factor (Rf) values, height and area of Ethanolic 0kra Ext at $10 \mathrm{mg} / \mathrm{ml}$ at $254 \mathrm{~nm}$ and unknown compounds

\begin{tabular}{|c|c|c|c|c|c|c|}
\hline Peak & Start Rf & Start Ht & Max Rf & Max Ht & Area & Assigned Subs \\
\hline 1 & 0.00 & 4.4 & 0.02 & 271.6 & 4528.9 & Unknown \\
\hline 2 & 0.10 & 20.6 & 0.11 & 25.4 & 474.3 & Unknown \\
\hline 3 & 0.15 & 14.2 & 0.15 & 15.6 & 298.2 & Substance 5 \\
\hline 4 & 0.19 & 4.5 & 0.21 & 44.5 & 1088.2 & Substance 4 \\
\hline 5 & 0.24 & 8.5 & 0.26 & 17.2 & 283.9 & unknown \\
\hline 6 & 0.27 & 14.8 & 0.29 & 20.2 & 381.8 & Substance 3 \\
\hline 7 & 0.30 & 22.0 & 0.32 & 27.4 & 538.4 & Substance 2 \\
\hline 8 & 0.37 & 4.4 & 0.42 & 74.2 & 1865.4 & unknown \\
\hline 9 & 0.44 & 51.8 & 0.44 & 52.7 & 978.1 & Unknown \\
\hline 10 & 0.49 & 13.5 & 0.49 & 14.6 & 264.4 & Unknown \\
\hline 11 & 0.54 & 0.57 & 23.3 & 668.7 & 6.02 & Substance 1 \\
\hline
\end{tabular}


8B. Track $8 \mathrm{ID}$ of Ethanolic Ext at $10 \mathrm{mg} / \mathrm{ml}$ at $356 \mathrm{~nm}$

Peak table with retention factor (Rf) values, height and area of Ethanolic Okra Ext at $10 \mathrm{mg} / \mathrm{ml}$ at $356 \mathrm{~nm}$ and unknown compounds

\begin{tabular}{|c|c|c|c|c|c|c|c|}
\hline Peak & Start Rf & Start Ht & Max Rf & Max Ht & Area & Area \% & Assigned Subs \\
\hline 1 & 0.00 & 4.8 & 0.02 & 133.7 & 3657.6 & 22.02 & Unknown \\
\hline 2 & 0.10 & 4.3 & 0.11 & 9.2 & 154 & 0.93 & Unknown \\
\hline 3 & 0.12 & 8.3 & 0.13 & 10.2 & 156.7 & 0.94 & Substance 7 \\
\hline 4 & 0.17 & 6.7 & 0.21 & 167.4 & 4172.6 & 25.12 & Substance 6 \\
\hline 5 & 0.24 & 23.8 & 0.26 & 68.9 & 1491.0 & 8.98 & Substance 5 \\
\hline 6 & 0.29 & 10.6 & 0.32 & 49.9 & 1146.7 & 6.90 & Substance 4 \\
\hline 7 & 0.34 & 10.8 & 0.36 & 21.5 & 486.4 & 2.93 & Substance 3 \\
\hline 8 & 0.40 & 9.4 & 0.42 & 35.3 & 736.3 & 4.43 & Unknown \\
\hline 9 & 0.44 & 23.7 & 0.45 & 25.4 & 419.5 & 2.53 & Unknown \\
\hline 10 & 0.47 & 15.2 & 0.48 & 16.4 & 370.3 & 2.23 & Unknown \\
\hline 11 & 0.53 & 11.4 & 0.57 & 50.3 & 1819.1 & 10.95 & Substance2 \\
\hline 12 & 0.66 & 11.4 & 0.69 & 17.1 & 393.0 & 2.37 & Unknown \\
\hline 13 & 0.75 & 17.2 & 0.76 & 20.4 & 304.1 & 1.83 & Substance 8 \\
\hline 14 & 0.82 & 16.9 & 0.84 & 21.6 & 420.1 & 2.53 & Unknown \\
\hline 15 & 0.88 & 21.7 & 0.91 & 31.9 & 883.5 & 5.32 & Substance 1 \\
\hline
\end{tabular}

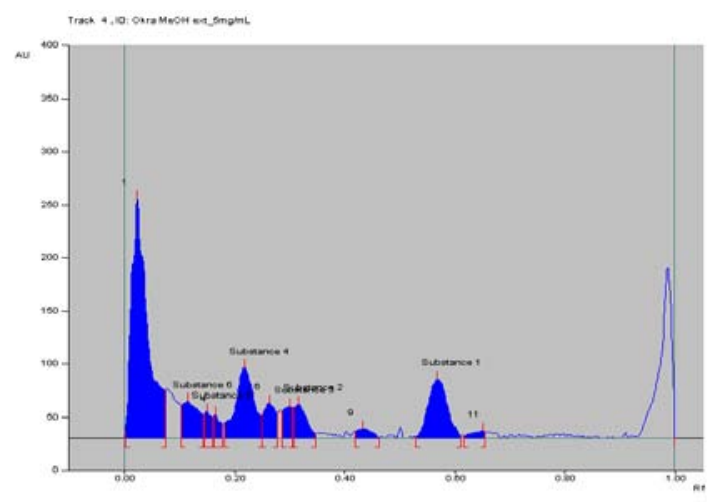

Fig. 4: Peak display of Okra MeOH at $254 \mathrm{~nm}$

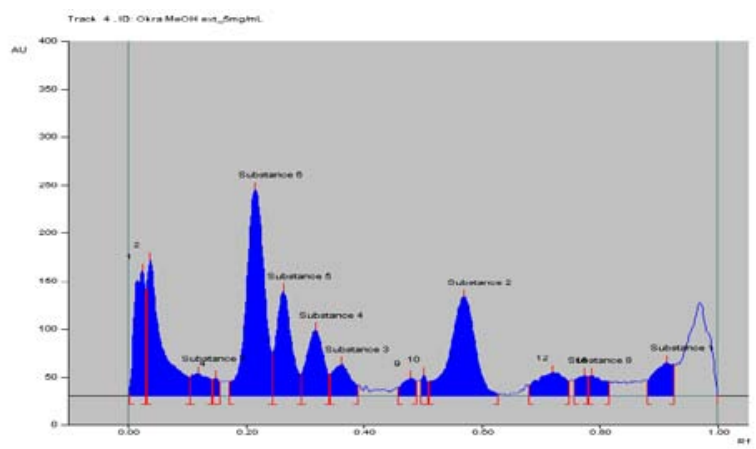

Fig. 5: Peak display of Okra MeOH at $356 \mathrm{~nm}$

Table 9: High-performance thin-layer chromatography densitogram and peaks of methanolic extract of okra mucilage at $254 \mathrm{~nm}$ and $356 \mathrm{~nm}$

9A: Track 4 ID of methanolic Ext at $5 \mathrm{mg} / \mathrm{ml}$ at $254 \mathrm{~nm}$

Peak table with retention factor (Rf) values, height and area of methanolic okra Ext at $5 \mathrm{mg} / \mathrm{ml}$ at $254 \mathrm{~nm}$ and unknown compounds

\begin{tabular}{|c|c|c|c|c|c|c|c|}
\hline Peak & Start Rf & Start ht & Max Rf & Max Ht & Area & Area\% & Assigned Subs \\
\hline 1 & 0.00 & 5.4 & 0.02 & 225.9 & 5902.2 & 44.48 & unknown \\
\hline 2 & 0.10 & 31.0 & 0.11 & 34.7 & 974.3 & 7.34 & Subs 6 \\
\hline 3 & 0.14 & 22.2 & 0.15 & 25.2 & 291.4 & 2.20 & Subs 5 \\
\hline 4 & 0.16 & 20.0 & 0.16 & 21.9 & 249.5 & 1.88 & unknown \\
\hline 5 & 0.18 & 14.9 & 0.22 & 66.7 & 1981.3 & 14.93 & Subs4 \\
\hline 6 & 0.25 & 21.5 & 0.26 & 33.5 & 623.7 & 4.70 & unknown \\
\hline 7 & 0.29 & 25.4 & 0.30 & 29.7 & 454.4 & 3.42 & Subs 3 \\
\hline 8 & 0.31 & 29.4 & 0.32 & 32.4 & 672.0 & 5.06 & Subs 2 \\
\hline 9 & 0.42 & 6.4 & 0.43 & 8.9 & 278.5 & 1.65 & unknown \\
\hline 10 & 0.53 & 1.4 & 0.57 & 55.8 & 1746.0 & 13.16 & Subs 1 \\
\hline 11 & 0.62 & 2.5 & 0.65 & 7.0 & 156.3 & 1.18 & unknown \\
\hline
\end{tabular}


9B: Track 4 ID of Methanolic Ext at $5 \mathrm{mg} / \mathrm{ml}$ at $356 \mathrm{~nm}$ :

Peak table with retention factor (Rf) values, height and area of methanolic 0kraExt at $5 \mathrm{mg} / \mathrm{ml}$ at $356 \mathrm{~nm}$ and unknown compounds

\begin{tabular}{|c|c|c|c|c|c|c|c|}
\hline Peak & Start Rf & Start Ht & Max Rf & Max Ht & Area & Area \% & Assigned subs \\
\hline 1 & 0.00 & 3.0 & 0.02 & 130.5 & 2100 & 8.54 & Unknown \\
\hline 2 & 0.03 & 111.3 & 0.04 & 141.9 & 3269.1 & 13.29 & Unknown \\
\hline 3 & 0.10 & 20.0 & 0.12 & 24.0 & 610.7 & 2.48 & Substance 7 \\
\hline 4 & 0.14 & 18.2 & 0.15 & 18.8 & 192.7 & 0.78 & Unknown \\
\hline 5 & 0.17 & 15.0 & 0.21 & 215.8 & 5789.1 & 23.53 & Substance 6 \\
\hline 6 & 0.24 & 45.1 & 0.26 & 109.6 & 3490.2 & 10.12 & Substance 5 \\
\hline 7 & 0.29 & 23.0 & 0.32 & 69.1 & 1753.2 & 7.13 & Substance 4 \\
\hline 8 & 0.34 & 22.5 & 0.36 & 33.3 & 901.2 & 3.66 & Substance 3 \\
\hline 9 & 0.46 & 9.3 & 0.48 & 18.7 & 385.1 & 1.57 & Unknown \\
\hline 10 & 0.49 & 16.0 & 0.50 & 22.8 & 202.4 & 0.82 & Unknown \\
\hline 11 & 0.51 & 15.1 & 0.57 & 103.3 & 3920.4 & 15.93 & Substance 2 \\
\hline 12 & 0.68 & 11.0 & 0.72 & 24.7 & 1054.9 & 4.29 & Unknown \\
\hline 13 & 0.76 & 17.3 & 0.77 & 21.6 & 358.3 & 1.46 & Substance 8 \\
\hline 14 & 0.78 & 20.6 & 0.79 & 21.8 & 513.2 & 2.09 & Unknown \\
\hline 15 & 0.88 & 16.4 & 0.91 & 34.8 & 1058.9 & 4.30 & Substance 1 \\
\hline
\end{tabular}

\section{Procedure to estimate amino acid in okra mucilage}

Chromatogram fingerprinting for amino acid was performed for both methanolic and ethanolic extract of okra mucilage at $610 \mathrm{~nm}$. High-performance thin-layer chromatography densitogram and peak table with retention factor (Rf) values, height and area of methanolic and ethanolic extract samples and Arginine and Methionine standards were depicted in table 10. The total amino acid in okra methanolic extract is $11.45 \% \mathrm{w} / \mathrm{w}$. Total Amino acid in okra Ethanolic extract $12.66 \% \mathrm{w} / \mathrm{w}$. The densitogram and 3D display were illustrated in fig. $6,7,8,9$ and 10 respectively.

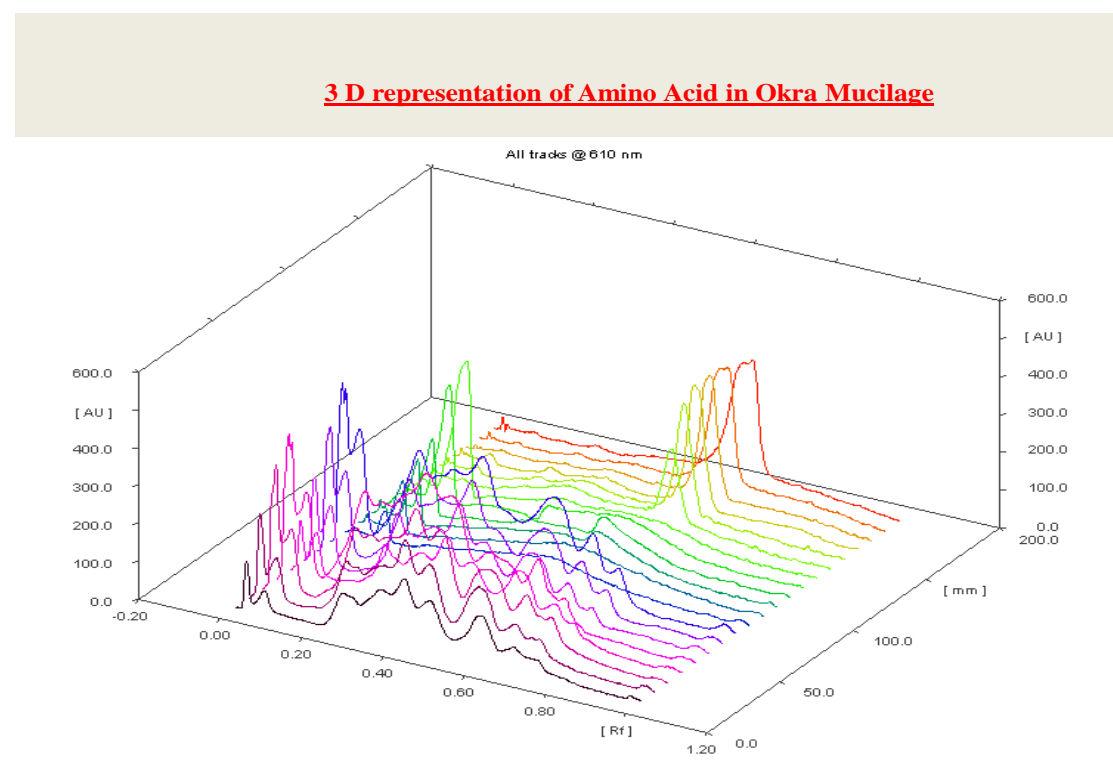

Fig. 6: High-performance thin-layer chromatography fingerprinting overlay of ethanolic and methanolic extract of okra mucilage for estimation of amino acid at $610 \mathrm{~nm}$ : no of tracks: 20

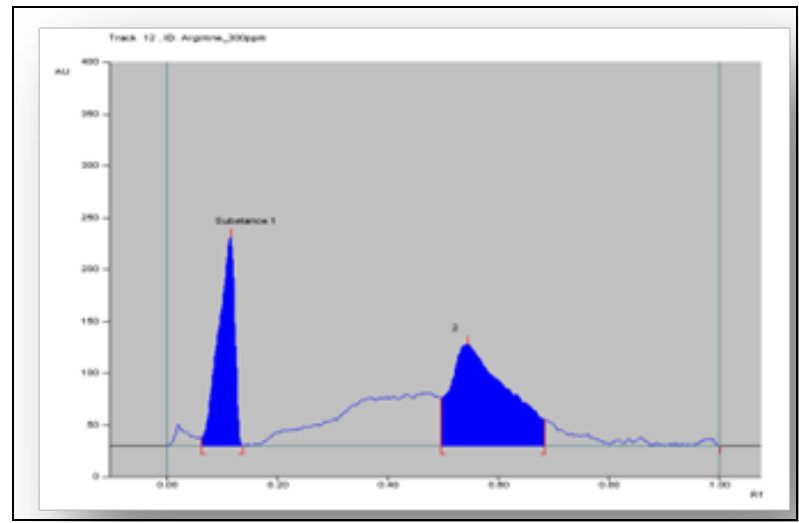

Fig. 7: Peak display of Arginine 300 ppm 


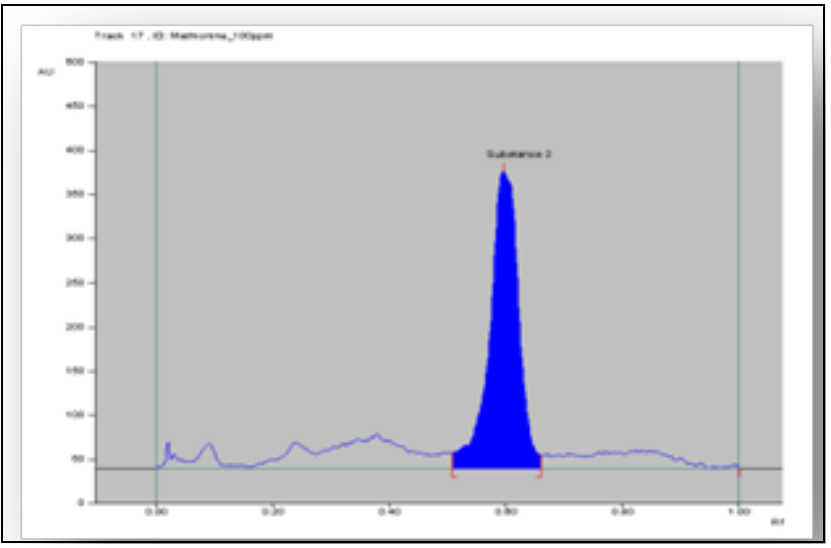

Fig. 8: Peak display of methionine 100 ppm

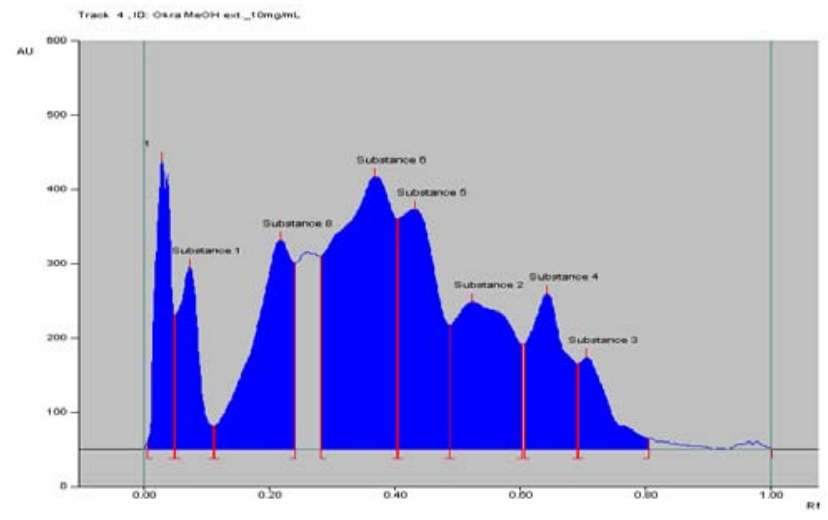

Fig. 9: Peak displayof okra Meo Hext 10 mg/ml

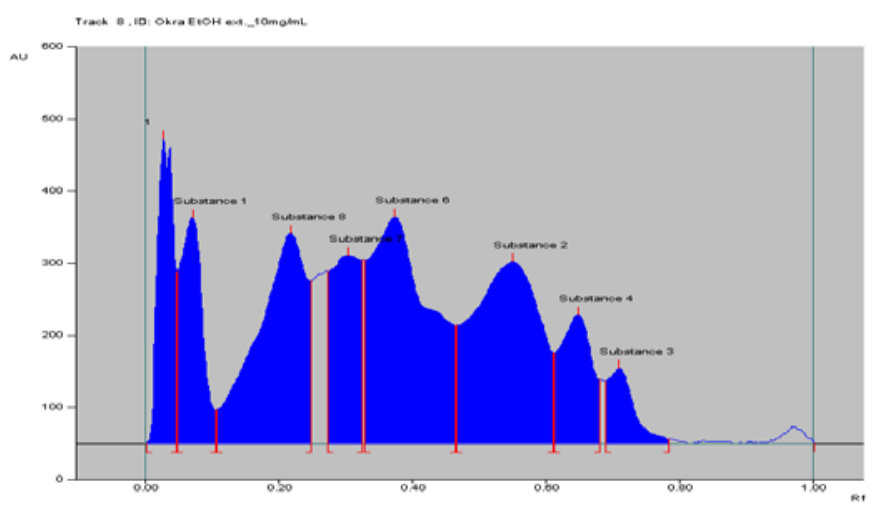

Fig. 10: Peak display of Okra Et0 ext at10 mg/ml

Table 10: 10A. Track 4: Methanolic extract $10 \mathrm{mg} / \mathrm{ml}$

Peak table with retention factor (Rf) values, height and area of Methanolic Okra Ext for presence of various amino acid at $10 \mathrm{mg} / \mathrm{ml}$ at 610 nm

\begin{tabular}{|c|c|c|c|c|c|c|c|}
\hline Peak & Start Rf & Start Ht & Max Rf & Max Ht & Area & Area \% & Assigned Subs \\
\hline 1 & 0.00 & 9.3 & 0.03 & 388.7 & 3107.7 & 7.38 & Unknown \\
\hline 2 & 0.05 & 181.3 & 0.07 & 245.3 & 7020.1 & 0.93 & Substance 1 \\
\hline 3 & 0.11 & 31.9 & 0.22 & 282.2 & 15868.2 & 0.94 & Substance 8 \\
\hline 4 & 0.28 & 259.3 & 0.37 & 367.5 & 29393.4 & 25.12 & Substance 6 \\
\hline 5 & 0.40 & 310.6 & 0.43 & 323.5 & 17169.7 & 8.98 & Substance 5 \\
\hline 6 & 0.49 & 167.7 & 0.52 & 198.6 & 16050.0 & 6.90 & Substance 2 \\
\hline 7 & 0.61 & 142.5 & 0.64 & 210.1 & 10456.2 & 2.93 & Substance 4 \\
\hline 8 & 0.69 & 115.3 & 0.72 & 124.6 & 5208.6 & 4.43 & Substance 3 \\
\hline
\end{tabular}


10B. Track 8: Ethanolic extract: $10 \mathrm{mg} / \mathrm{ml}$ :

Peak table with retention factor (Rf) values, height and area of Ethanolic Okra Ext for presence of various amino acid at $10 \mathrm{mg} / \mathrm{ml}$ at 610 nm

\begin{tabular}{|c|c|c|c|c|c|c|c|}
\hline Peak & Start Rf & Start Ht & Max Rf & Max Ht & Area & Area \% & Assigned Subs \\
\hline 1 & 0.00 & 0.3 & 0.03 & 422.8 & 8869.1 & 8.38 & Unknown \\
\hline 2 & 0.05 & 239.0 & 0.07 & 313.6 & 9097.4 & 8.60 & Substance 1 \\
\hline 3 & 0.10 & 46.2 & 0.22 & 291.7 & 18831.2 & 0.94 & Substance 8 \\
\hline 4 & 0.27 & 238.8 & 0.30 & 261.0 & 10380.6 & 25.12 & Substance 7 \\
\hline 5 & 0.33 & 255.0 & 0.37 & 314.6 & 24774.0 & 8.98 & Substance 6 \\
\hline 6 & 0.46 & 164.0 & 0.55 & 252.7 & 22669.2 & 6.90 & Substance 2 \\
\hline 7 & 0.61 & 126.0 & 0.65 & 178.4 & 7542.4 & 2.93 & Substance 4 \\
\hline 8 & 0.69 & 86.6 & 0.71 & 104.8 & 3664.5 & 4.43 & Substance 3 \\
\hline
\end{tabular}

10C. Track 10: Arginine 100 ppm

Peak table with retention factor (Rf) values, height and area of standard Arginine $100 \mathrm{ppm}$ at $610 \mathrm{~nm}$

\begin{tabular}{llllllll}
\hline Peak & Start Rf & Start Ht & Max Rf & Max Ht & Area & Area \% & Assigned Subs \\
\hline 1 & 0.06 & 7.3 & 0.11 & 136.0 & 3140.9 & 39.21 \\
2 & 0.49 & 49.1 & 0.51 & 72.2 & Substance 1 & unknown & 60.79 \\
\hline
\end{tabular}

10D: Track: 17: Methionine 100 ppm

Peak table with retention factor (Rf) values, height and area of standard Methionine $100 \mathrm{ppm}$ at $610 \mathrm{~nm}$

\begin{tabular}{lllllll}
\hline Peak & Start Rf & Start Ht & Max Rf & Max Ht & Area & Area \% \\
\hline 1 & 0.51 & 17.3 & 0.60 & 336.3 & 14687.6 & 100 \\
\hline
\end{tabular}

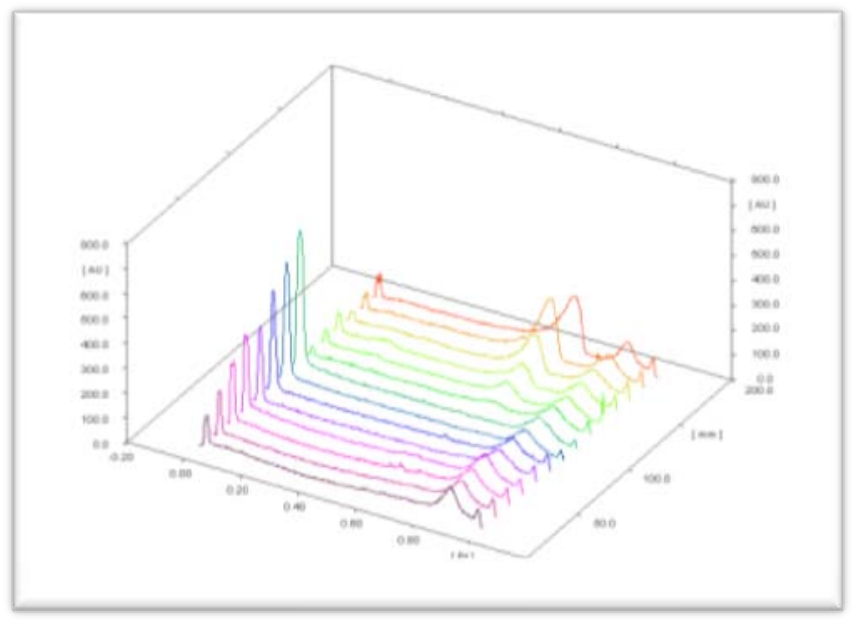

Fig. 11: High-performance thin-layer chromatography fingerprinting overlay of ethanolic and methanolic extract of okra mucilage for estimation of ascorbic acid at $254 \mathrm{~nm}$ : no of tracks: 14

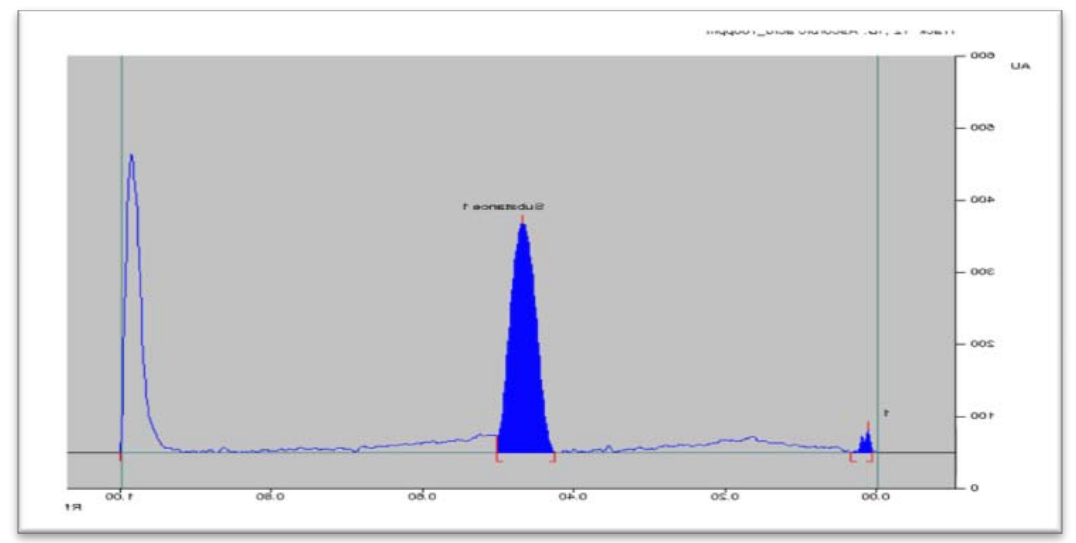

Fig. 12: Peak display of standard ascorbic acid 100 ppm 


\section{Procedure to estimate ascorbic acid in okra mucilage extract}

HPTLC fingerprinting for ascorbic acid in okra mucilage was performed for both methanolic and ethanolic extract. The HPTLC fingerprinting overlay of ethanolic and methanolic extract of okra mucilage for estimation of Ascorbic acid at $254 \mathrm{~nm}$ were depicted in table 11. The ascorbic acid content in okra (Methanolic) and (Ethanolic) was found to be $0.24 \% \mathrm{w} / \mathrm{w}$ and $0.18 \% \mathrm{w} / \mathrm{w}$ respectively. The densitogram and 3D display were illustrated in fig. 11.1213 and 14 , respectively.

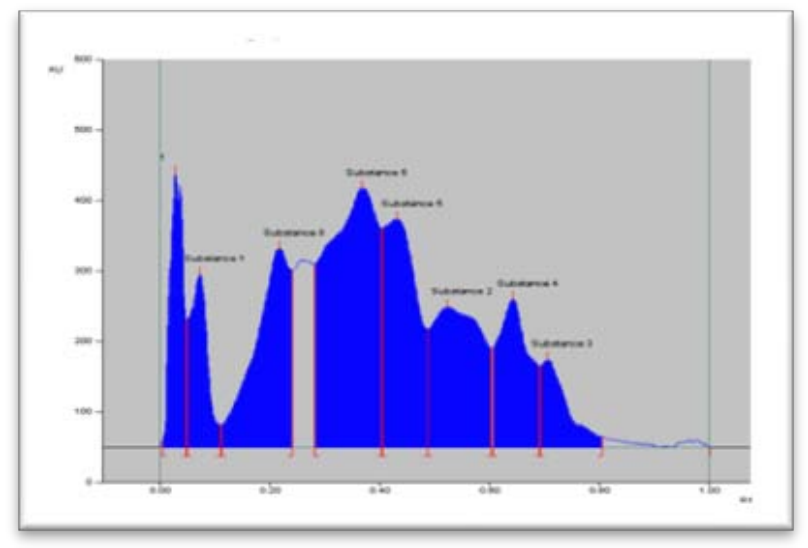

Fig. 13: Peak display of okra methanolic ext10 mg/ml

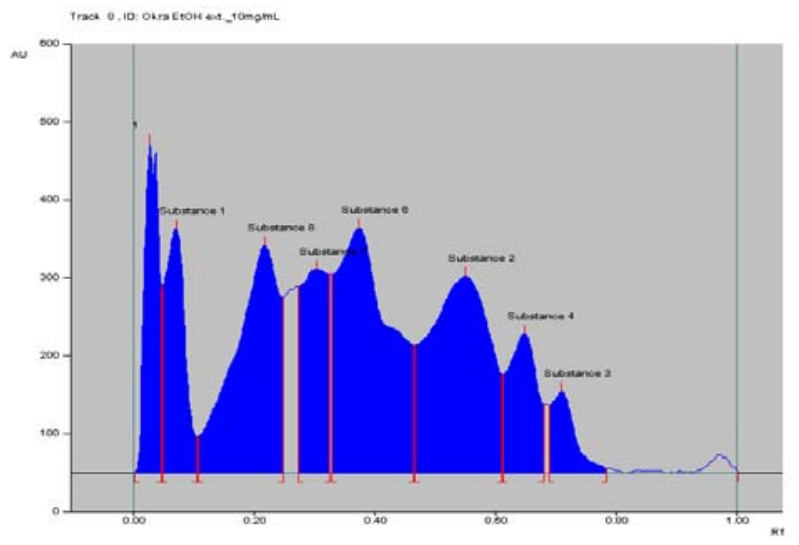

Fig. 14: Peak display of okra ethanolic extract $10 \mathrm{mg} / \mathrm{ml}$

Table 11: High-performance thin-layer chromatography densitogram and Peak table with retention factor (Rf) values, height and area of samples methanolic and ethanolic extract of okra mucilage and standards ascorbic acid

11A Track 2 ID: Okra MeOH ext $10 \mathrm{mg} / \mathrm{ml}$ :

Peak table with retention factor (Rf) values, height and area of Okra Methanolic ext $10 \mathrm{mg} / \mathrm{ml}$ at $254 \mathrm{~nm}$

\begin{tabular}{|c|c|c|c|c|c|c|c|}
\hline Peak & Start Rf & Start Ht & Max Rf & Max Ht & Area & Area \% & Assigned Subs \\
\hline 1 & 0.01 & 0.4 & 0.02 & 185.0 & 2724.0 & 20.32 & Substance 1 \\
\hline 2 & 0.10 & 12.1 & 0.11 & 12.9 & 269.0 & 2.01 & unknown \\
\hline 3 & 0.19 & 6.7 & 0.20 & 9.8 & 237.6 & 1.77 & unknown \\
\hline 4 & 0.56 & 10.9 & 0.57 & 17.1 & 270.8 & 2.08 & Substance 4 \\
\hline 5 & 0.63 & 15.4 & 0.65 & 20.3 & 369.8 & 2.76 & Substance 1 \\
\hline 6 & 0.68 & 21.0 & 0.69 & 25.7 & 479.8 & 3.58 & unknown \\
\hline 7 & 0.78 & 29.5 & 0.87 & 103.7 & 7985.4 & 59.56 & Substance 2 \\
\hline 8 & 0.96 & 24.9 & 0.98 & 66.7 & 1070.6 & 7.98 & unknown \\
\hline
\end{tabular}

11B. Track 6: ID: Okra Ethanolic ext $10 \mathrm{mg} / \mathrm{ml}$

Peak table with retention factor (Rf) values, height and area of Okra Methanolic ext $10 \mathrm{mg} / \mathrm{ml} \mathrm{at} 254 \mathrm{~nm}$

\begin{tabular}{|c|c|c|c|c|c|c|c|}
\hline Peak & Start Rf & Start Ht & Max Rf & Max Ht & Area & Area \% & Assigned Subs \\
\hline 1 & 0.00 & 0.0 & 0.02 & 400.6 & 6455.3 & 45.97 & unknown \\
\hline 2 & 0.62 & 8.2 & 0.63 & 21.3 & 278.6 & 1.98 & Substance 1 \\
\hline 3 & 0.73 & 11.7 & 0.74 & 16.5 & 210.9 & 1.50 & Substance 3 \\
\hline 4 & 0.80 & 23.3 & 0.87 & 85.4 & 5586.2 & 39.78 & Substance 2 \\
\hline 5 & 0.93 & 30.6 & 0.93 & 35.8 & 530.3 & 3.78 & Unknown \\
\hline 6 & 0.96 & 19.9 & 0.99 & 60.8 & 982.3 & 6.99 & unknown \\
\hline
\end{tabular}


11C. Track 10 ID: Ascorbic Acid Std 100 ppm

Peak table with retention factor (Rf) values, height and area of standard Ascorbic Acid $100 \mathrm{ppm}$ at $254 \mathrm{~nm}$

\begin{tabular}{|c|c|c|c|c|c|c|c|}
\hline Peak & Start Rf & Start Ht & Max Rf & Max Ht & Area & Area \% & Assigned Subs \\
\hline 1 & 0.01 & 0.2 & 0.02 & 56.6 & 785.7 & 8.54 & unknown \\
\hline 2 & 0.08 & 0.0 & 0.10 & 7.6 & 59.5 & 0.65 & unknown \\
\hline 3 & 0.15 & 3.7 & 0.16 & 12.3 & 135.3 & 1.47 & unknown \\
\hline 4 & 0.17 & 6.0 & 0.18 & 11.6 & 155.6 & 1.69 & unknown \\
\hline 5 & 0.19 & 9.2 & 0.20 & 12.1 & 209.1 & 2.27 & unknown \\
\hline 6 & 0.52 & 1.7 & 0.53 & 6.4 & 55.9 & 0.61 & unknown \\
\hline 7 & 0.58 & 9.3 & 0.59 & 14.7 & 146.9 & 1.60 & Unknown \\
\hline 8 & 0.60 & 15.1 & 0.65 & 53.8 & 3094.9 & 33.65 & Substance 1 \\
\hline 9 & 0.78 & 5.9 & 0.87 & 67.8 & 4056.2 & 44.10 & Substance 2 \\
\hline 10 & 0.92 & 27.0 & 0.92 & 28.3 & 498.1 & 5.42 & Unknown \\
\hline
\end{tabular}

The Rf value for substance 1 in the TRACK 10 of standard ascorbic acid100 ppm was found to be 0.60 and peak area 3094.9. The Rf value of substance 1in the TRACK 6 of Okra Ethanolic ext $10 \mathrm{mg} / \mathrm{ml}$ in the second peak of the sample coinciding nearly to standard Ascorbic Acid $100 \mathrm{ppm}$ was found to be 0.62 and peak area 278.6. The fifth peak of substance 1 in TRACK 2 Okra Methanolic ext $10 \mathrm{mg} / \mathrm{ml}$ was found to be 0.63 and peak area 369.8 coinciding nearly with standard Rf value(0.60) and peak area 3094.9of Ascorbic Acid $100 \mathrm{ppm}$ at peak 8 of Track 10 .

\section{Spectrophotmetric Analysis of total polyphenol content present} in Okra mucilage extract

Determination of the total phenolic content was done both for ethanolic and methanolic extracts of okra mucilage. Phytochemical screening of the ethanolic and methanolic extracts of okra mucilage was conducted, and the presence of phenolics was observed for both the extracts showed (Latif A. Zeenat, Siddiqui N., Rauf A-2013). Folin
Denim's method reagentwas used for the total phenolic contents in terms of the tannic acid equivalent (TAE) in $\mathrm{mg} / \mathrm{g}$ of the extract. Calculation for the total phenolic content wasdone with the help of the graph shown in fig. 15, and the standard curve equation was $y=0.007 x+0.047$, where $R^{2}=0.999$ The total phenolic contents (tannic acid equivalents, $\mathrm{mg} / \mathrm{g}$ ) in the methanolic extracts and ethanolic extracts were calculated to be $4.6 \% \mathrm{w} /$ and $5.3 \% \mathrm{w} / \mathrm{w}$ respectively.

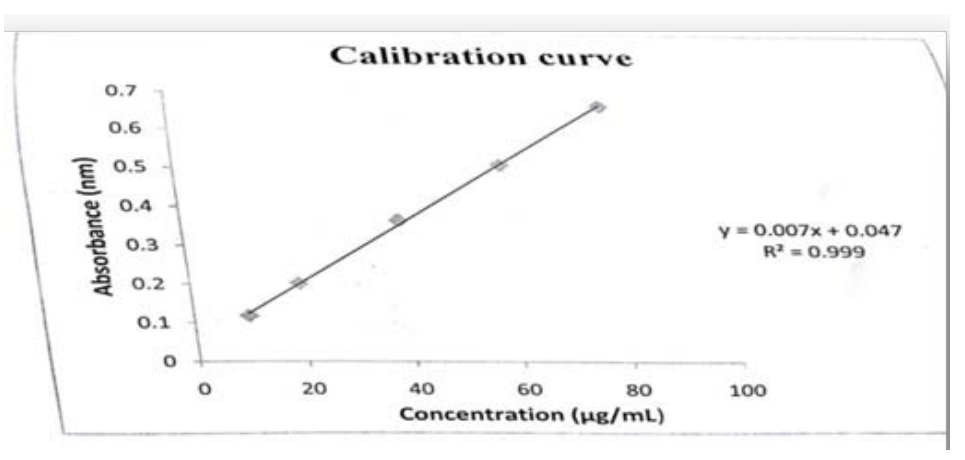

Fig. 15: Standard tannic acid curve for the total polyphenol content

The total phenolic contents were calculated using the following linear equation based on the calibration curve of tannic acid

$$
\mathrm{Y}=0.007 X+0.0477, R^{2}=0.999
$$

Calculation of total polyphenol $(\mu \mathrm{g} / \mathrm{mg})$

Sample solution concentration $(\mu \mathrm{g} / \mathrm{ml})$ by calibration curve $\mathrm{x}$ dilution fold $\mathrm{x}$ solution volume $\mathrm{x}$ purty of standard

$$
\text { Sample weight }
$$

\section{CONCLUSION}

Thus, the present study provides us with adequate information about the identification, standardization, and quality control of okra fruit mucilage and also about the the therapeutic efficacy of the okra mucilage

This analytical method can be used for its various analysis in plant materials and also in routine quality control laboratories and research zone for the raw materials as well as formulations containing this compound. Also to confirm the purity, safety and efficacy of okra mucilage the analytical method can be used. Also the study showed that the procedure used for the extraction of mucilages by two differe nt solvents methanolic and ethanolic was efficient. Moreover the outcome of the organoleptic, physicochemical and phytochemical analysis exhibits that mucilage derived from okra fruit can be used in pharmaceutical dosage form as additive ingredient. The analysis of the current research reveal that with the incorporation of green analytical technology in evaluation, identification and authentication of the crude mucilage will be helpul in setting up of the Quality Control Standards.

Moreover both methanolic and ethanolic extracts of okra mucilage can be used for further studies as potential source in various pharmaceutical preparations.

Thus from the HPTLC profiling, we can derive the conclusion that HPTLC analysis is an important parameter to be used for herbal drug standardization. Moreover both the methanolic extract and ethanolic extract contains a mixture of compounds and not only single component which indicates that the pharmacological activity shown by them are due to the additive effect of all the compounds present in the extract.

\section{ACKNOWLEDGEMENT}

We are very pleased to acknowledge the Director (Dr) Muruganandam. A. V of Natreon Inc Salt Lake City KOLKATA (Branch office, India) with principal office in, USA. for providing the facilities for carrying out the experiments. We are also very thankful to Dr Anjan K. Mohanty and Dr. Biswajit Chakra borty for their encouragement and support during conducting the studies.

\section{FUNDING}

Nil 


\section{AUTHORS CONTRIBUTIONS}

All the authors have contributed equally.

\section{CONFLICTS OF INTERESTS}

The authors declare that there are no conflicts of interest.

\section{REFERENCES}

1. O Ogunyemi. The origin of herbal cure and its spread. In Proceedings of the conference on African Medicinal Plants, A. Sofowora Ed. Ile-Ife University Press; 1979. p. 20-2.

2. Raymond CR, Paul JS, Sian CO. Handbook of pharmaceutical excipients. $5^{\text {th }}$ ed. London (UK): The Pharmaceutical Press; 2006.

3. GT Kulkarni, K Gowthamarajan, RR Dhobe, F Yohanan, B Suresh. Development of controlled release spheriods using natural polysaccharide as release modifier. Drug Delivery $2005 ; 12: 201$

4. H Hamman, J Steenekamp. Use of natural gums and mucilages as pharmaceutical excipients. Curr Pharma 2015;21:4775-97.

5. Prajapati, GK Jani, NG Moradiya, NP Randeria. Pharmaceutical applications of various natural gums, mucilages and their modified forms. Carbohydr Polym 2013;92:1685-99.

6. Thakur M, Bhargava S, Praznik W, Loeppert R, Dixit VK. Effect of chlorophytumborivilianum santapau and fernandes on sexual dysfunction inhyperglycemic male rats. Chinese I Integrative Med 2009:15:448-53.

7. Dominguez Lopez A. Use of the fruit and stems of the prickly pearcactus (Opuntia spp.) into human food. Food Sci Technol Int 1995;1:65-74.

8. $\mathrm{R}$ Malviya. Extraction characterization and evaluation of selected mucilage as pharmaceutical excipient. Polim Med 2011;41:39-44.

9. Kalu VD, Odeniyi MA, Jaiyeoba KT. Matrix properties of a new plant gum in controlled drug delivery. Arch Pharm Res 2007;30:884-9.

10. Nasipuri RN, Igwilo CI, Brown SA, Kunle 00. Mucilage from Abelmoschus esculentus fruits-a potential pharmaceutical raw material. J Pharm Res Dev 1996;1:22-28.
11. Dharani B, Sumathi S, Sivaprabha J. In vitro antioxidant potential of prosopis cineraria leaves. J Nat Prod Plant Resour 2011;1:26e32.

12. $\mathrm{N}$ Tavakoli, $\mathrm{R}$ Teimouri, H Hamishehkar. Characterization and evaluation of Okra gum as a tablet binder. Jundushapur J Nat Pharm Prod 2007;3:33-8.

13. Ameena K, Dilip C, Saraswathi R, Krishnan PN, Sankar C, Simi SP. Isolation of the mucilages from Hibiscus rosa sinensis linn. and Okra (Abelmoschus esculentus Linn.) and studies of the binding effects of the mucilages. Asian Pac J Trop Med 2010;3:539-43.

14. Manjule DB, Gazi S, Surwase U, Bhalchandra K. Isolation and characterization of Hibiscus rosa sinensis linn. (shoe flowers plant). Int J Pharm Chem Sci 2012;1:942-7.

15. Ohwoavworhua FO, Adelakun TA. Some physical characteristics of microcrystalline cellulose obtained from raw cotton of Cochlospermumplanchonii. Trop J Pharm Res 2005;4:1-7.

16. Khandelwal KR. Practical pharmacognosy techniques and experiments. $15^{\text {th }}$ ed. Nirali Prakashan; 2008. p. 29.

17. Tyler VE, Brady LR, Robbers JE. Pharmacognosy Lea and Febiger, Philadelphia; 1976. p. 24.

18. Bhat V, Nayak R, Praveena MB, Cox PA, MJ Balick. The ethnobotanical approach to drug discovery. Sci Am 1994;270:82-7.

19. GT Kulkarni, K Gowthamarajan, RR Dhobe, F Yohanan, B Suresh. Development of controlled release spheriods using natural polysaccharide as release modifier. Drug Delivery 2005;12:201.

20. Whistler RL. Exudate gums. In: Whistler RL, Bemiller JN. editors. Industrial Gums: Polysaccharides and their derivatives. San Diego, Academic Press; 1993. p. 318-37.

21. Puttewar TY, Kshirsagar MD, Chandewar AV, Chikhale RV. Formulation and evaluation of or dispersible tablet of taste masked doxylamine succinate using ion exchange resin. J King Saud Univ Sci 2010;22:229-40.

22. Joshi Y, Chaudhary RK, Teotia UV. Formulation and evaluation of diclofenac sodium sustained release matrix tablets using Aegle marmelosgum. Int J Curr Trends Pharm Res 2013;1:174. 